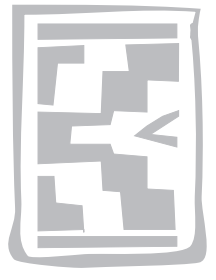

\title{
Evaluation of larvicides in developing management guidelines for long-term control of pest blackflies (Diptera: Simuliidae) along the Orange River, South Africa
}

\author{
R.W. PALMER ${ }^{1 *}$ and N.A. RIVERS-MOORE ${ }^{2}$
}

\begin{abstract}
PALMER, R.W. \& RIVERS-MOORE, N.A. 2008. Evaluation of larvicides in developing management guidelines for long-term control of pest blackflies (Diptera: Simuliidae) along the Orange River. Onderstepoort Journal of Veterinary Research, 75:299-314

In 2000 and 2001 Orange River levels were higher than normal: associated serious outbreaks of blackfly had a substantial detrimental impact on the local economy. The poor control was attributed to the suspected development of larval resistance to temephos. A long-term solution to blackfly control, through the identification of a suitable replacement to temephos for use during high flow conditions, was proposed. This study, however, failed to identify or register a suitable larvicide for use during high flow conditions. Although permethrin was highly effective against blackfly larvae, it was rejected because of its detrimental impacts on non-target fauna. Various formulations of locally produced dry Bacillus thuringiensis var. israelensis (B.t.i.) were tested, but these were ineffective against blackflies. The study also confirmed that resistance to temephos has developed among Simulium chutteri in the middle and lower Orange River. The feasibility of "reversing" the resistance to temephos through the use of the synergist piperonyl butoxide (PBO) was investigated, but the results were not favourable. Furthermore, PBO was highly toxic to blackflies and non-target organisms, and was not recommended for further testing. This means that B.t.i. currently remains the only symptomatic measure of treatment currently applied. Although resistance to B.t.i. has not been reported for blackflies elsewhere in South Africa, there is a need to remain vigilant and to implement an operational strategy that minimizes the risks of resistance developing.
\end{abstract}

Keywords: Larvicide trials, Orange River, pest blackflies, resistance, Simuliidae

\section{INTRODUCTION}

Outbreaks of pest blackflies (Diptera: Simuliidae) have been one of the most serious problems affecting agriculture and tourism along the middle and lower Orange River following the completion of the Gariep and Vanderkloof Dams in the late 1970s (Palmer 1997; Myburgh \& Nevill 2003). The blackfly

* Author to whom correspondence is to be directed. E-mail: rob@nepid.co.za

1 Nepid Consultants, P.O. Box 4349, White River, 1240 South Africa

2 Institute for Water Research, P.O. Box 94, Rhodes University, Grahamstown, 6140 South Africa

Accepted for publication 14 August 2008-Editor problem is attributed mainly to high winter flows, which provide suitable habitat for over-wintering blackfly larvae. The main pest species is Simulium chutteri, although there are times when Simulium damnosum and Simulium impukane are problematic. Adult female blackflies usually need a blood meal to complete the development of eggs, and their large numbers and tendency to crawl into ears, noses and eyes, make them problematic to livestock and people. All outdoor activities are seriously affected, particularly stock farming, irrigation farming, river rafting and other tourist activities.

Chemical control of pest blackfly in South Africa began in the 1960s with the use of DDT, a wide-spectrum larvicide (Howell \& Holmes 1969). In 1991 the 
Department of Agriculture initiated a programme to control these pests along the middle and lower Orange River (Palmer 1997). The programme was initially based on aerial applications of two larvicides, namely temephos, an organophosphate, with Abate ${ }^{\circledR} 200$ EC being the only product registered for use in South Africa, and the bacterium Bacillus thuringiensis var. israelensis (B.t.i.), with Teknar® HP-D and Vectobac ${ }^{\circledR} 12 \mathrm{AS}$ being two products registered for use in South Africa.

The bacterial larvicides, which contain protein toxins produced by the naturally occurring soil bacterium B.t.i. are generally the preferred method of blackfly control because of their high target specificity and low impact on the environment. However, these products are relatively bulky and are suitable for use when flows in the Orange River are moderate to low $\left(<100 \mathrm{~m}^{3} / \mathrm{s}\right)$. At river levels exceeding $300 \mathrm{~m}^{3} / \mathrm{s}$ it becomes difficult to airlift the volumes needed to treat the Orange River effectively. Under these conditions it is preferable to use Abate ${ }^{\circledR} 200 E C$, an organophosphate that is more concentrated and easier to airlift than B.t.i.

Between 1991 and 1999 the control programme was supported by research conducted by the Onderstepoort Veterinary Institute with funding from the Water Research Commission and the Red Meat Producers Organization. The research aimed to ensure that the control programme was both effective and environmentally safe (Palmer 1997; Myburgh 1999). The control programme was highly effective during this period, but research was discontinued in 1999. Serious outbreaks of blackflies were experienced in 2000 and 2001 as a result of river levels being higher than normal, and this led to appeals from organ- ized agriculture for the problem to be rectified, and for a long-term solution be found. The aim of this study was to find a suitable larvicide for use against blackflies in the Orange River during high flow conditions. The findings of the dispersal properties of various products and their toxicity to blackfly larvae and common non-target organisms, using flowthrough gutters and field trials are described.

\section{MATERIALS AND METHODS}

\section{Study area}

The main study area for this project was the Orange River downstream of Vanderkloof Dam (Fig. 1). The Great Fish River near Grahamstown was also used to conduct trails to investigate larval resistance to temephos, as the river contains populations of the main pest species, $S$. chutteri, which had not previously been exposed to temephos. Alternative larvicides were tested in the Orange River at Upington, and in various rivers near Grahamstown, in the Eastern Cape Province. The latter were chosen because of the availability of mean daily flow data, and their small size which reduced the volume of larvicide needed.

\section{Criteria for evaluation}

The criteria used to evaluate the larvicides were based on a hypothetical ideal larvicide which should have the following characteristics:

- Effective against blackflies and target specific

- Easy to airlift and apply

- Disperses rapidly and evenly in water

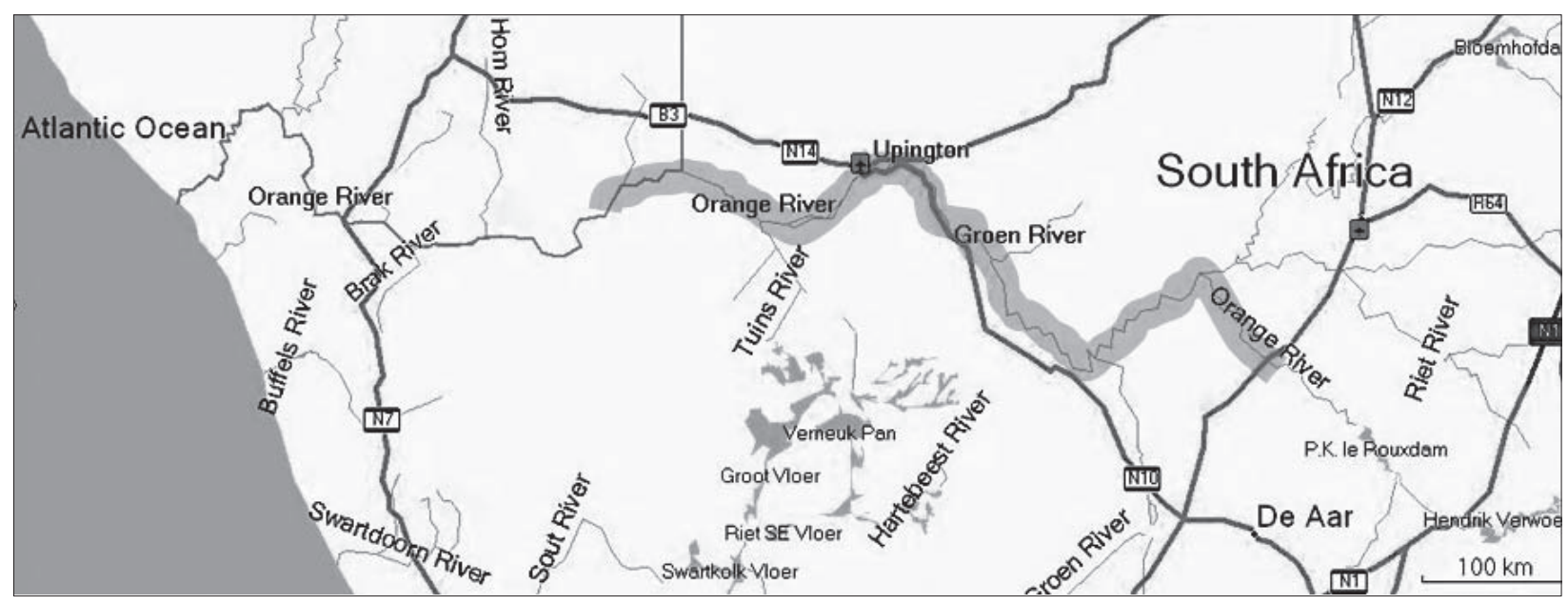

FIG. 1 Map of the middle and lower Orange River downstream of Van der Kloof Dam (formerly PK le Roux Dam), with the main blackfly problem area highlighted in grey 
- Carries for long distances downstream

- Good shelf life

- Cheap

- Safe to handle

- Without problems of cross resistance with temephos.

\section{Larvicides selected for evaluation}

This study was limited to investigating currently available commercial products for blackfly control, as it was well beyond its budget and scope to investigate new products for development. The study relied largely on the experience of the World Health Organization's Onchocerciasis Control Programme in West Africa (OCP). The OCP has tested over 50 larvicides and hundreds of formulations for use against pest blackflies since it inception in 1974 (Kurtak, Back, Chalifour, Doannio, Dossou-Yove, Duval, Guillet, Meyer, Ocran \& Wahle 1989). Most of the tests were conducted during the early phases of the OCP. The OCP was discontinued in 2002 (Lévêque et al. 2003), and since then very few investigations of new products for blackfly control have been undertaken. The larvicides that were most commonly used by the OCP are listed in Table 1. This provided a good starting point for identifying a suitable larvicide for use in the Orange River. The use of alternative organophosphates was not considered because of the possible cross-resistance with temephos, while the use of carbamates was not considered because of the high impacts on non-target fauna. The most suitable candidate was therefore one of the synthetic pyrethroids, a group of powerful broadspectrum insecticides (Mueller-Beilschmidt 1990) which act as neurotoxins. The two pyrethroid compounds that were commonly used in West Africa were permethrin and etofenprox. Although permethrin is more toxic to non-target aquatic fauna than etofenprox, it has a lower mammalian toxicity. Permethrin is particularly suited for large rivers and was considered to be the most suitable candidate larvicide for testing in South Africa. While synthetic pyrethroids generally degrade to varying degree by exposure to light, permethrin is a newer, light-stable pyrethroid (Mueller-Beilschmidt 1990).

Several agrochemical companies were contacted for samples of permethrin, or similar products to replace temephos, for trial purposes. The only company to express an interest in supplying alternative products to temephos was Wefco Marketing. The other companies approached indicated that they were not prepared to take the risk, mainly because of legal implications and public concerns about environmental safety. Wefco Marketing suggested using piperonyl butoxide (PBO) in combination with temephos, as piperonyl butoxide combined with temephos or permethrin has the ability to "reverse" the

TABLE 1 Main characteristics of the blackfly larvicides used by Onchocerciasis Control Programme in West Africa. [Data from Dr Jean-Marc Hougard, Institut de Recherche pour le Développement, France]

\begin{tabular}{|c|c|c|c|c|c|c|c|c|}
\hline \multirow{2}{*}{\multicolumn{2}{|c|}{$\begin{array}{l}\text { Family } \\
\text { Common name }\end{array}$}} & \multicolumn{3}{|c|}{ Organophosphates } & \multicolumn{2}{|l|}{ Pyrethroids } & \multirow{2}{*}{$\begin{array}{l}\text { Carbamate } \\
\text { Carbosulfan }\end{array}$} & \multirow{2}{*}{$\begin{array}{l}\text { Bacteria } \\
\text { B.t. } \mathrm{H}-14\end{array}$} \\
\hline & & Temephos & Phoxim $^{1}$ & Pyraclofos & Permethrin & Etofenprox & & \\
\hline \multicolumn{2}{|c|}{ Formulation } & $\mathrm{EC}^{2}$ & EC & EC & EC & $\mathrm{EC}$ & EC & $W^{3}$ \\
\hline \multicolumn{2}{|c|}{$\%$ active ingredient } & 20 & 50 & 50 & 20 & 30 & 25 & $<2$ \\
\hline \multicolumn{2}{|c|}{ Toxicity class ${ }^{4}$} & III & II & II & II & III & II & III \\
\hline \multicolumn{2}{|c|}{ Toxicity against NTF5 } & Low & Medium & Medium & High & Medium & High & Low \\
\hline \multicolumn{2}{|l|}{ Dose $^{6}$} & $150^{7}$ & 150 & 120 & 45 & 60 & 120 & 500 \\
\hline \multirow{3}{*}{$\begin{array}{l}\text { Average } \\
\text { carry at } \\
(\mathrm{km})\end{array}$} & $10 \mathrm{~m}^{3} / \mathrm{s}$ & 12 & 3 & Unused & Unused & Unused & Unused & 1.5 \\
\hline & $100 \mathrm{~m}^{3} / \mathrm{s}$ & 16 & 5 & 18 & 7 & 6 & 9 & 5 \\
\hline & $300 \mathrm{~m}^{3} / \mathrm{s}$ & 20 & Unused & 23 & 8 & 8 & Unused & Unused \\
\hline \multicolumn{9}{|c|}{ Chlorphoxim until 1991} \\
\hline \multicolumn{9}{|c|}{ Emulsion concentrate } \\
\hline \multicolumn{9}{|c|}{ Water dispersible } \\
\hline \multicolumn{9}{|c|}{ According to the WHO (1988) classification of active ingredient: II, moderately hazardous; III, slightly hazardous } \\
\hline \multicolumn{9}{|c|}{ Toxicity against non-target fauna according to the criteria of the Ecological Group } \\
\hline \multicolumn{9}{|c|}{ In $\mathrm{m} \ell$ of formulation per $\mathrm{m}^{3} / \mathrm{s}$} \\
\hline \multicolumn{9}{|c|}{$300 \mathrm{m \ell}$ in clear water } \\
\hline
\end{tabular}


Larvicides in developing management guidelines for control of pest blackflies (Diptera: Simuliidae), South Africa

TABLE 2 Products and formulations tested during this study for potential use for blackfly control

\begin{tabular}{|l|l|l|l|}
\hline Active ingredient & Class & Formulation & Suppliers \\
\hline B.t.i. & Bacterial toxin & $\begin{array}{l}\text { Dry powder } 500: 500^{1} \\
\text { Dry powder } 500: 250^{2} \\
\text { Slow-release granules }\end{array}$ & Plant Health Products \\
\hline Permethrin & Pyrethroid & $\begin{array}{l}\text { Larvex } \mathrm{TM} 0.5 \% \mathrm{w} / \mathrm{v} \\
\text { RD } 95 / \mathrm{A} 200 \mathrm{~g} / \ell \\
\text { RD } 95 / \mathrm{B} 200 \mathrm{~g} / \ell \\
\text { Permethrin }(\text { unlabelled) }\end{array}$ & Wefco Marketing \\
\hline Piperonyl butoxide & Synergist & $\begin{array}{l}\text { RD } 96 \mathrm{~A} \\
\text { RD } 96 / \mathrm{B} \\
\text { PBO (unlabelled) }\end{array}$ & Wefco Marketing \\
\hline Temephos & & Abate $\AA 200 \mathrm{EC}$ & $\begin{array}{l}\text { SA Cyanamid } \\
\text { BASF } \\
\text { Wefco Marketing }\end{array}$ \\
\hline
\end{tabular}

1 Formulation consists of $500 \mathrm{~g}$ B.t.i. fermentation broth plus $500 \mathrm{~g}$ carrier, mixed and dried down

2 Formulation is twice as concentrated as the 500:500 dry powder, and consists of $500 \mathrm{~g}$ B.t.i. fermentation broth plus $250 \mathrm{~g}$ carrier, mixed and dried down

development of resistance (Jones 1998). Larvicide synergy is a useful approach since the combined exposure of two or more larvicides causes more adverse effects than the sum of their individual effects (Cox 1998). This opened the possibility of continuing with the operational use of temephos, but trials were needed on blackflies from non-resistant populations, such as the Great Fish River, as well as on presumed resistant populations in the Orange River. Wefco Marketing supplied small quantities of four formulations of permethrin and three formulations of PBO for initial trials, while BASF supplied small quantity of Abate® ${ }^{\circledR}$ 200EC.

Another possible option was the use of a powdered formulation of B.t.i., which would be lighter and therefore more easily air lifted than the standard liquid concentrate, particularly during high flow conditions. Although the operational application of powdered formulations of B.t.i. could be a problem because of wind and equipment available, the powder could be mixed with water prior to application. Plant Health Products supplied small quantities of two locally produced powdered and granular B.t.i. formulations for initial testing, which were toxic to mosquitoes (M. Morris, personal communication 2005). The products and formulations tested during this study are listed in Table 2.

\section{Dispersal properties}

The dispersal properties of the various products were observed by mixing the product with various volumes of water and applying this mixture to a jar of standing clear water. This simple test provided a rapid visual indication of how the product is likely to behave when applied in a river and was used as the first step in screening potential larvicides. Formulations that were buoyant or sank to the bottom were immediately rejected.

\section{Viscosity}

Viscosity of B.t.i. products can be a serious problem, so the relative viscosity of the B.t.i. was measured by filling a small $(125 \mathrm{ml})$ cup containing a small hole (approx. $3 \mathrm{~mm}$ in diameter), and timing the cup to empty. This was performed four times for each of two B.t.i. concentrations ( 8 and $24 \mathrm{~g} / \mathrm{l}$ ) plus a control of $0 \mathrm{~g} / \ell$.

\section{Gutter trials}

Gutter trials were conducted in the Great Fish River at the Pigott's Bridge gauging weir (Q9H012), $40 \mathrm{~km}$

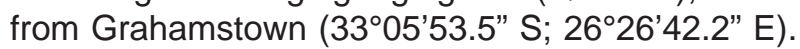
This site was chosen because of accessibility, the weir provided sufficient head that allowed water to be gravitated into the gutters, and there were high populations of $S$. chutteri within close proximity to the trial site. The trials were conducted using a flowthrough four-gutter system in which river water gravitated from the gauging weir. The gutters were $3.45 \mathrm{~m}$ long and $0.15 \mathrm{~m}$ wide and were made of a galvanized tin alloy (Fig. 2). Blackfly larvae were obtained from the main river ( 5 min walk away) by cutting lengths of Cyperus reeds which were trailing in fast current. Twenty reeds were placed in each gutter and wedged in position using $0.20 \mathrm{~m}$ lengths of dowels. Larvae were given at least $1.5 \mathrm{~h}$ to settle 


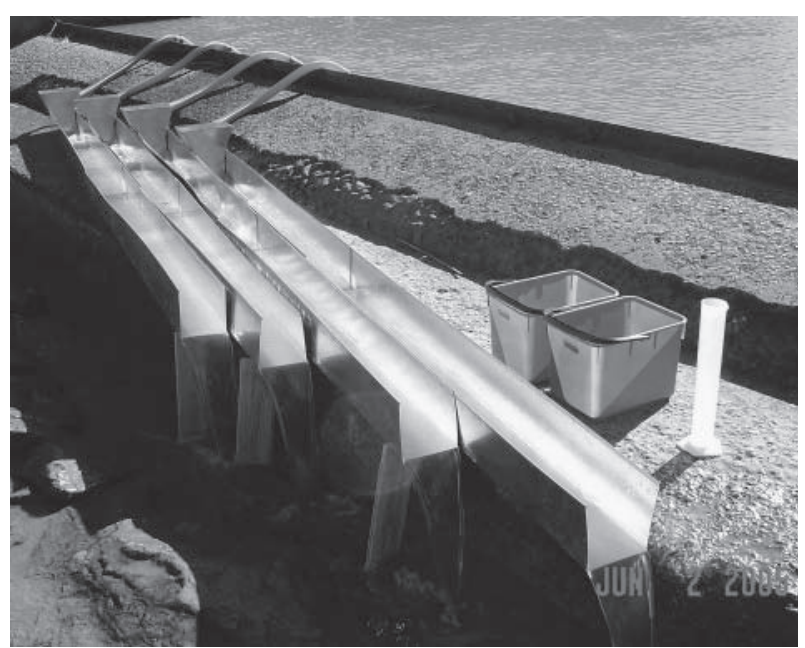

FIG. 2 Flow-through gutter system used for larvicide trials on S. chutteri larvae

before exposure to chemical larvicides, whereas for B.t.i. trials larvae were given an $1.5 \mathrm{~h}$ to settle. The only species of blackfly that was present was $S$. chutteri.

Flow in each gutter was determined prior to each application by holding a container $(11.8 \ell)$ at the exit of each channel and timing it to fill. Larvicide was applied over $10 \mathrm{~min}$ in the header chamber at the top end of each gutter to ensure homogenous mixing, using a $60 \mathrm{ml}$ syringe. Water temperature at the time of each application was recorded. Larval mortality was assessed $1 \mathrm{~h}$ after application for chemical products and $24 \mathrm{~h}$ for B.t.i. products. The assessment was based on the abundance of live larvae in an untreated control gutter and compared with the abundance of live larvae in treated gutters. Abundance of larvae was based on a 10-point visual ranking method described by Palmer (1994). The abundance ratings were converted to population densities to determine efficacy, although this method is unlikely to detect mortalities less than $50 \%$. At least 15 counts were made per gutter.

\section{Field trials}

\section{Belmont Valley}

Field trials were undertaken at two sites in the Belmont Valley near Grahamstown (Site 1:

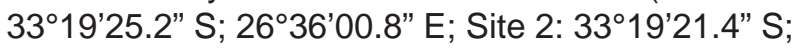
$26^{\circ} 36^{\prime} 49.7^{\prime \prime}$ E). The stream was chosen because of its small size, close proximity to Grahamstown and high populations of blackflies. A road bridge crosses the stream and culverts were used to measure the stream flow using Equations 1a-c (Gordon et al. 1992).

$$
\begin{aligned}
& Q=1000 v A \\
& A=0.5 r^{2}(\theta-\operatorname{Sin} \theta) \\
& \theta=2 \cos ^{-1}\left(\frac{r-d}{r}\right)
\end{aligned}
$$

where $Q=$ discharge in $\ell / \mathrm{s} ; v=$ average current speed in $\mathrm{m} / \mathrm{s} ; A=$ cross-sectional area in $\mathrm{m}^{2} ; \theta$ is in radians.

The only species of blackfly that was present at Site 1 was the pest species Simulium nigritarse, but Simulium adersi was also present further downstream at Site 2. Larvicide was applied with a $1 \ell$ hand-held garden sprayer over a period of $8 \mathrm{~min}$. Water temperature at the time of the application was recorded. Larval mortality was assessed $3 \mathrm{~h}$ after application for chemical trials and $24 \mathrm{~h}$ after application for B.t.i. trials. The assessment of efficacy was based on the abundance of live larvae on the stones-in-current in an untreated stretch of stream compared to the abundance of live larvae in the treated section, before and after application. Abundance of larvae and assessment of efficacy was based on the same method as used for the gutter trials, and sample size was also at least 15 stones or reeds.

\section{Buffalo River}

A field trial was undertaken in Eastern Cape Province in the Buffalo River at a gauging weir near King William's Town (R2H010-32॰56'26.5” S; 27²7'41.3” E). The site was chosen because of the high populations of blackflies and close proximity to an accurate gauging weir. The most common species of blackfly that was present was Simulium hargreavesi, but other species present were Simulium vorax, S. nigritarse and $S$. damnosum. Larvicide was again applied with a $1 \ell$ hand-held garden sprayer over a period of $8 \mathrm{~min}$. Water temperature at the time of the application was recorded. Larval mortality was assessed $3 \mathrm{~h}$ after application. The assessment of efficacy was based on the abundance of live larvae in the stonesin-current in before and after application. Abundance of larvae was based on the same method as used in the gutter trials. At least 15 counts were made.

\section{Orange River}

Field trials were conducted in the Orange River at Upington and Kanoneiland in August 2005 and October 2006. For the earlier trials, the same methods as those described above were used. The most common species present was $S$. chutteri, although S. damnosum was also present. In the latter field trials, two formulations of Abate $\AA$ 200EC were applied by boat, one to each of two channels on either side of the Orange River at Kanoneiland. 


\section{Impacts on non-target organisms}

Impact of permethrin on non-target organisms was evaluated during selected field trials. Population densities of aquatic invertebrates were estimated before and after application using the visual method of assessment developed for estimating blackfly populations (Palmer 1994).

\section{RESULTS}

\section{Dispersal properties}

Initial screening of the physical behaviour of the products in water showed that permethrin and piperonyl butoxide formulations dispersed well. Of the formulations tested, permethrin RD95B dispersed

TABLE 3 Viscosity (ml/s) for tap water and two concentrations of B.t.i. (500: 250)

\begin{tabular}{|c|c|c|c|}
\hline Sample & $\begin{array}{l}\text { Flow time (s): } 0 \mathrm{~g} / \ell \\
\text { (125 me tap water) }\end{array}$ & $\begin{array}{l}\text { Flow time }(\mathrm{s}): 8 \mathrm{~g} / \mathrm{\ell} \\
(1 \mathrm{~g} \text { in } 125 \mathrm{~m} \ell)\end{array}$ & $\begin{array}{l}\text { Flow time (s): } 24 \mathrm{~g} / \ell \\
(3 \mathrm{~g} \text { in } 125 \mathrm{ml})\end{array}$ \\
\hline 1 & 37.9 & 39.4 & 38.1 \\
\hline 2 & 38.5 & 37.3 & 37.9 \\
\hline 3 & 36.8 & 37.5 & 37.6 \\
\hline 4 & 38.5 & 36.8 & 37.4 \\
\hline Mean & 37.9 & 37.8 & 37.8 \\
\hline Flow rate $(\mathrm{m} \ell / \mathrm{s})$ & 3.3 & 3.3 & 3.3 \\
\hline
\end{tabular}

TABLE 4 Conditions of application and results of flow through gutter trials to test the toxicity of permethrin RD 95/B to blackfly larvae at Pigott's Bridge, Great Fish River

\begin{tabular}{|l|l|l|l|l|l|l|}
\hline Trial no. & Date & $\begin{array}{l}\text { Water temp. } \\
\left({ }^{\circ} \mathbf{C}\right)\end{array}$ & $\begin{array}{l}\text { Gutter } \\
\text { channel }\end{array}$ & $\begin{array}{l}\text { Flow } \\
(\ell / s)\end{array}$ & $\begin{array}{l}\text { Dosage } \\
(\mathbf{m g} / \ell)\end{array}$ & Efficacy (\%) \\
\hline 1 & 11.5 & 1 & 1.23 & 0.01626 & 98 \\
& 05.06 .05 & & 2 & 1.07 & 0.03738 & 99 \\
& & 3 & 1.28 & 0.04688 & 99 \\
& & & 4 & 1.01 & 0.09901 & 100 \\
& & & 1 & 1.76 & 0.00201 & 62 \\
\end{tabular}

TABLE 5 Conditions of application and results of field trials to test the toxicity of permethrin RD95B to blackfly larvae

\begin{tabular}{|c|c|c|c|c|c|c|}
\hline Trial no. & Date & Site & $\begin{array}{l}\text { Water temp. } \\
\left({ }^{\circ} \mathrm{C}\right)\end{array}$ & $\begin{array}{l}\text { Flow } \\
(\ell / s)\end{array}$ & $\begin{array}{l}\text { Dosage } \\
(\mathrm{mg} / \mathrm{\ell})\end{array}$ & Efficacy (\%) \\
\hline 1 & 03.05 .05 & $\begin{array}{l}\text { Belmont Valley } \\
\text { Site } 1\end{array}$ & 11.5 & 69 & $\begin{array}{l}0^{*} \\
0.024 \\
0.048\end{array}$ & $\begin{array}{r}0 \\
0 \\
63\end{array}$ \\
\hline 2 & 03.06 .05 & $\begin{array}{l}\text { Belmont Valley } \\
\text { Site } 2\end{array}$ & 12.0 & 69 & $\begin{array}{l}0^{*} \\
0.024 \\
0.048 \\
0.072\end{array}$ & $\begin{array}{r}0 \\
25 \\
88 \\
88\end{array}$ \\
\hline 3 & 06.06 .05 & Buffalo River & 12.0 & 279 & 0.050 & 99 \\
\hline 4 & 07.06 .05 & $\begin{array}{l}\text { Belmont Valley } \\
\text { Site } 1\end{array}$ & 11.0 & 91 & $\begin{array}{l}0 \\
0.02\end{array}$ & $\begin{array}{r}0 \\
82\end{array}$ \\
\hline 5 & 08.06 .05 & $\begin{array}{l}\text { Belmont Valley } \\
\text { Site } 1\end{array}$ & 10.0 & 70 & $\begin{array}{l}0 \\
0.040\end{array}$ & $\begin{array}{r}0 \\
83\end{array}$ \\
\hline 6 & 08.06 .05 & $\begin{array}{l}\text { Belmont Valley } \\
\text { Site } 2\end{array}$ & 10.2 & 70 & $\begin{array}{l}0 \\
0.030\end{array}$ & $\begin{array}{r}0 \\
56\end{array}$ \\
\hline
\end{tabular}

\footnotetext{
* Control
} 
the best by far. The Abate $\AA 2$ 200EC dispersed well. The density of Larvex ${ }^{\mathrm{TM}} 0.5 \% \mathrm{w} / \mathrm{v}$ was very low and floated on the surface, so this product was excluded from further testing. The standard formulation of powdered B.t.i. mixed well in water, but the more concentrated formulation was dense and settled rapidly when applied to water.

\section{Viscosity}

The powdered formulation of B.t.i. mixed well with small quantities of water, but the concentrated formulation formed sticky lumps when mixed in larger volumes. The viscosity of the supernatant was low and not significantly different from that of tap water (Student's $t$-test; $P<0.05$; d.f. $=3$ ) at concentrations of 8 and $24 \mathrm{~g} / \ell$ (Table 3 ). By contrast, the viscosity of the lumps of the concentrated formulation was exceedingly high. To undertake the viscosity trials the formulation was dissolved in a separate beaker prior to draining through a cup so as to prevent the drainage hole from being blocked with lumps.

\section{Larvicide trials}

\section{Permethrin}

\section{Gutter trials}

Gutter trials conducted at Pigott's Bridge confirmed that permethrin RD95B is highly effective against $S$. chutteri at dosages as low as $0.016 \mathrm{mg} / \ell$ (Table 4).

\section{River trials}

River trials conducted at two sites in the Belmont Valley indicated that permethrin achieved between $63 \%$ and $88 \%$ mortality of $S$. nigritarse at a dosage of $0.0483 \mathrm{mg} / \mathrm{l}$ (Table 5). The trials assumed that flows at the two sites were the same, but the results suggest that flows at the downstream site were slightly lower, and therefore dosages higher, than upstream. A subsequent trial in the Buffalo River achieved $99 \%$ mortality at a slightly higher dosage of $0.0502 \mathrm{mg} / \ell$ (Table 5).

Mortality curves for Simulium using permethrin RD95B were constructed for both gutter trial and river trial experiments. The mortality curve for the gutter trials was significant $(P<0.05$; d.f. $=8$; intercept $=9.80 \pm 0.75$; slope $=1.50 \pm 0.35$ ), while the mortality curve for the river trials was not significant $(P<0.05$; d.f. $=5$; intercept $=21.83 \pm 3.64$; slope $=$ $11.38 \pm 2.47)$. The $\mathrm{LC}_{50}$ values for gutter trials $(0.001 \mathrm{mg} / \ell)$ were, however, 30 times lower than for the river trials $(0.033 \mathrm{mg} / \mathrm{l})$, suggesting that the effects of higher flow rates may have an impact on

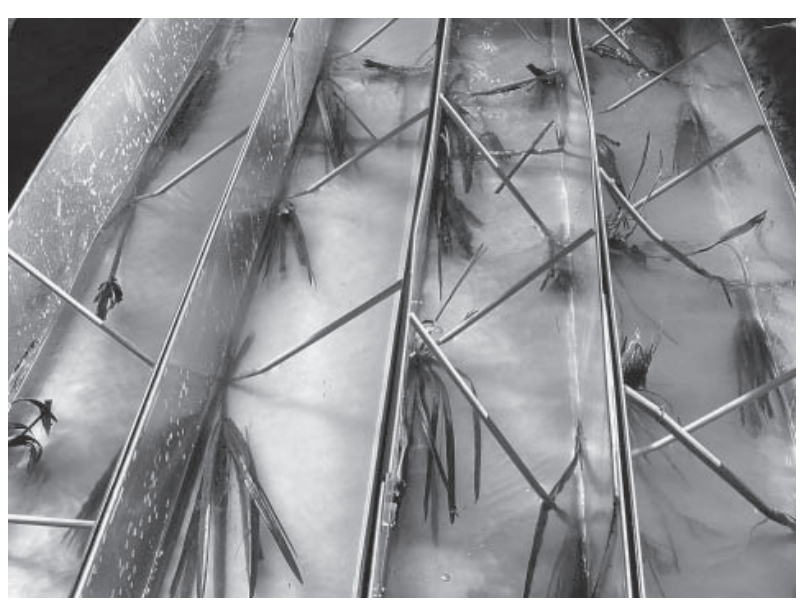

FIG. 3 Mortality curves for Simulium spp. based on applications of permethrin RD95B at different concentrations, for gutter and river trials

effective concentrations of permethrin (Fig. 3). Similar findings were made in West Africa, and the researcher recommended the use of a closed-circuit trough system for screening conventional larvicides for blackfly control (Ocran 1989).

\section{Impacts on non-target organisms}

A series of trials were conducted to assess the target specificity of permethrin in local rivers. Initial trials were conducted in the Bloukrans River near Grahamstown, and the Buffalo River near King Williams Town, because of their small size, ease of logistics and ability to measure stream flows.

Invertebrate diversity in the Bloukrans River was low prior to a trial application of permethrin in June 2005. Individuals of the caddisfly Macrostemum capense and Gyrinidae beetles were absent from these aquatic invertebrate communities, while Chironomids were present in low numbers only. The aquatic invertebrate communities were largely unaffected by applications of permethrin at concentrations of 0.02 , 0.03 and $0.04 \mathrm{mg} / \ell$ (Tables $6 \mathrm{~A}$ and $\mathrm{B}$ ). Invertebrates which were affected negatively by the application of permethrin were limpets (Ancylidae) and flatworms (Turbellaria).

The diversity of invertebrates in the Buffalo River, near King Williams Town, was very low prior to application because the site is highly polluted from domestic and industrial wastes. This meant that the fauna that were present were highly tolerant species. Despite this, the application of permethrin RD95B at a concentration if $0.05 \mathrm{mg} / \ell$ had major impacts on non-target organisms, particularly water boatmen and mayflies, followed by caddisflies and 
Larvicides in developing management guidelines for control of pest blackflies (Diptera: Simuliidae), South Africa

TABLE 6A Relative abundance of invertebrate taxa in the Bloukrans River (Belmont Valley Site 2) before and after application of permethrin at $0.03 \mathrm{mg} / \mathrm{l}$

\begin{tabular}{|l|l|l|l|}
\hline Taxa & Application & Rating & Efficacy (\%) \\
\hline $\begin{array}{l}\text { Turbellaria } \\
\text { (Flatworm) }\end{array}$ & Before & 221412121432211 & 99 \\
\hline $\begin{array}{l}\text { Ancylidae } \\
\text { (Limpets) }\end{array}$ & After & 11111112132124 & \\
\hline $\begin{array}{l}\text { Cheumatopsyche afra } \\
\text { (Caddisfly) }\end{array}$ & Before & 221212212212121 & 99 \\
\hline $\begin{array}{l}\text { Chironomidae } \\
\text { (non-biting Midge) }\end{array}$ & Before & 111212111111112 & 0 \\
\hline $\begin{array}{l}\text { Macrostemum capense } \\
\text { (Caddisfly) }\end{array}$ & After & 322333131341122 & 0 \\
\hline $\begin{array}{l}\text { Baetidae } \\
\text { (Mayfly) }\end{array}$ & After & 214122323211233 & 0 \\
\hline $\begin{array}{l}\text { Gyrinidae } \\
\text { (Water Boatmen) }\end{array}$ & Bfter & 111111111111111 & 0 \\
\hline
\end{tabular}

TABLE 6B Relative abundance of invertebrate taxa in the Bloukrans River (Belmont Valley Site 1) before and after application of permethrin at $0.04 \mathrm{mg} / \ell$

\begin{tabular}{|l|l|l|l|}
\hline Taxa & Application & Rating & Efficacy (\%) \\
\hline $\begin{array}{l}\text { Chironomidae } \\
\text { (non-biting midge) }\end{array}$ & Before & 111111111111111 & n/a \\
\hline $\begin{array}{l}\text { Ancylidae } \\
\text { (Limpets) }\end{array}$ & After & 21111111111111 & 0 \\
\hline $\begin{array}{l}\text { Cheumatopsyche afra } \\
\text { (Caddisfly) }\end{array}$ & After & 133322221222232 & 0 \\
\hline $\begin{array}{l}\text { Turbellaria } \\
\text { (Flatworm) }\end{array}$ & Before & 123111322122222 & 0 \\
\hline $\begin{array}{l}\text { Macrostemum capense } \\
\text { (Caddisfly) }\end{array}$ & Before & 121211112221232 & 0 \\
\hline $\begin{array}{l}\text { Baetidae } \\
\text { (Mayfly) }\end{array}$ & After & 121211112121212 & 0 \\
\hline $\begin{array}{l}\text { Gyrinidae } \\
\text { (Water boatmen) }\end{array}$ & After & 221232222232222 & \\
\hline
\end{tabular}

flatworms (Table 6C). The only taxon that appeared to be unaffected was non-biting midges. The numbers of non-biting midges appeared to increase after application, but this was probably because they were small and must have been largely overlooked prior to application, whereas after application they were about the only fauna left alive, so they were more visible.

The intention was to use permethrin for blackfly control in the Orange River, so a trial was conducted to investigate its impacts on non-target fauna in the Orange River. Permethrin was applied at a concen- tration of $0.1 \mathrm{ppm}$ from a road bridge to the left channel of the river at the Kanoneiland. The composition of aquatic invertebrates was assessed before and after application at Blaauwskop, $5.4 \mathrm{~km}$ downstream of the bridge. The application had a devastating impact on non-target fauna: $100 \%$ mortality was recorded for various families of mayflies, damselflies, water boatmen and hydroptilid caddisflies (Table 6D). Prior to application the population of blackfly larvae was very high, but very few $(3 \%)$ survived the application. Other taxa that were detrimentally affected included non-biting midges, limpets and two species of caddisfly that are important 
R.W. PALMER \& N.A. RIVERS-MOORE

TABLE 6C Relative abundance of invertebrate taxa in the Buffalo River before and after application of permethrin at $0.05 \mathrm{mg} / \ell$

\begin{tabular}{|l|l|l|l|}
\hline Taxa & Application & Rating & Efficacy (\%) \\
\hline $\begin{array}{l}\text { Gyrinidae } \\
\text { (Water Boatmen) }\end{array}$ & Before & 211212222222222 & 100 \\
\hline $\begin{array}{l}\text { Baetidae } \\
\text { (Mayfly) }\end{array}$ & After & 111111111111111 & \\
\hline $\begin{array}{l}\text { Macrostemum capense } \\
\text { (Caddisfly) }\end{array}$ & After & 322323434433353 & 99 \\
\hline $\begin{array}{l}\text { Turbellaria } \\
\text { (Flatworm) }\end{array}$ & Before & 11121111111111 & \\
\hline $\begin{array}{l}\text { Cheumatopsyche afra } \\
\text { (Caddisfly) }\end{array}$ & Before & 321221211411112 & 89 \\
\hline $\begin{array}{l}\text { Ancylidae } \\
\text { (Limpets) }\end{array}$ & After & 111211111112111 & 74 \\
\hline $\begin{array}{l}\text { Chironomidae } \\
\text { (non-biting Midge) }\end{array}$ & After & 221231212462132 & 69 \\
\hline
\end{tabular}

TABLE 6D Relative abundance of invertebrate taxa in the Orange River River before and after application of permethrin at $0.10 \mathrm{mg} / \mathrm{\ell}$ at Kanoleiland, left channel, $5.4 \mathrm{~km}$ upstream, at discharge of $12.92 \mathrm{~m} 3 / \mathrm{s}$, on 14/08/2005

\begin{tabular}{|c|c|c|c|}
\hline Taxa & Application & Rating & Efficacy (\%) \\
\hline $\begin{array}{l}\text { Baetidae } \\
\text { (Mayfly) }\end{array}$ & $\begin{array}{l}\text { Before } \\
\text { After }\end{array}$ & $\begin{array}{l}111224123231112 \\
111111111111111\end{array}$ & 100 \\
\hline $\begin{array}{l}\text { Heptageniidae } \\
\text { (Mayfly) }\end{array}$ & $\begin{array}{l}\text { Before } \\
\text { After }\end{array}$ & $\begin{array}{l}112331112134111 \\
111111111111111\end{array}$ & 100 \\
\hline $\begin{array}{l}\text { Leptophlebiidae } \\
\text { (Mayfly) }\end{array}$ & $\begin{array}{l}\text { Before } \\
\text { After }\end{array}$ & $\begin{array}{l}113411113114121 \\
111111111111111\end{array}$ & 100 \\
\hline $\begin{array}{l}\text { Gyrinidae } \\
\text { (Water Boatmen) }\end{array}$ & $\begin{array}{l}\text { Before } \\
\text { After }\end{array}$ & $\begin{array}{l}211112221111121 \\
111111111111111\end{array}$ & 100 \\
\hline $\begin{array}{l}\text { Coenagrionidae } \\
\text { (Damselfly) }\end{array}$ & $\begin{array}{l}\text { Before } \\
\text { After }\end{array}$ & $\begin{array}{l}1121211111111111 \\
111111111111111\end{array}$ & 100 \\
\hline $\begin{array}{l}\text { Hydroptilidae } \\
\text { (Caddisfly) }\end{array}$ & $\begin{array}{l}\text { Before } \\
\text { After }\end{array}$ & $\begin{array}{l}112211111121111 \\
111111111111111\end{array}$ & 100 \\
\hline $\begin{array}{l}\text { Simuliidae } \\
\text { (Blackfly) }\end{array}$ & $\begin{array}{l}\text { Before } \\
\text { After }\end{array}$ & $\begin{array}{l}81567767716677(10) \\
502513143331121\end{array}$ & 97 \\
\hline $\begin{array}{l}\text { Chironomidae } \\
\text { (non-biting Midge) }\end{array}$ & $\begin{array}{l}\text { Before } \\
\text { After }\end{array}$ & $\begin{array}{l}89688818877188(10) \\
664555555177777\end{array}$ & 82 \\
\hline $\begin{array}{l}\text { Ancylidae } \\
\text { (Limpets) }\end{array}$ & $\begin{array}{l}\text { Before } \\
\text { After }\end{array}$ & $\begin{array}{l}111241323231122 \\
112111311111111\end{array}$ & 80 \\
\hline $\begin{array}{l}\text { Amphipsyche scottae } \\
\text { (Caddisfly) }\end{array}$ & $\begin{array}{l}\text { Before } \\
\text { After }\end{array}$ & $\begin{array}{l}331132241531312 \\
221113211112122\end{array}$ & 63 \\
\hline $\begin{array}{l}\text { Cheumatopsyche thomasseti } \\
\text { (Caddisfly) }\end{array}$ & $\begin{array}{l}\text { Before } \\
\text { After }\end{array}$ & $\begin{array}{l}231121233331322 \\
321311213221221\end{array}$ & 35 \\
\hline $\begin{array}{l}\text { Turbellaria } \\
\text { (Flatworm) }\end{array}$ & $\begin{array}{l}\text { Before } \\
\text { After }\end{array}$ & $\begin{array}{l}113111235311225 \\
203411113451111\end{array}$ & 18 \\
\hline $\begin{array}{l}\text { Ecnomidae } \\
\text { (Caddisfly) }\end{array}$ & $\begin{array}{l}\text { Before } \\
\text { After }\end{array}$ & $\begin{array}{l}111111111121211 \\
121112111111111\end{array}$ & $\mathrm{n} / \mathrm{a}$ \\
\hline $\begin{array}{l}\text { Elmidae } \\
\text { (Beetle) }\end{array}$ & $\begin{array}{l}\text { Before } \\
\text { After }\end{array}$ & $\begin{array}{l}2111111111111121 \\
111111121111111\end{array}$ & $\mathrm{n} / \mathrm{a}$ \\
\hline
\end{tabular}


predators of blackflies, Cheumatopsyche thomasseti and Amphipsyche scottae. The results were conclusive evidence that permethrin is unsuitable for use in the Orange River because of its detrimental impact on non-target fauna.

\section{Temephos and piperonyl butoxide}

\section{Gutter trials}

Gutter trials using the Abate $\AA$ 200EC formulation of temephos showed that the product was effective against $S$. chutteri in the Great Fish River, but ineffective in the Orange River (Table 7).
Gutter trials conducted at Pigott's Bridge, Great Fish River, indicated that piperonyl butoxide RD95B is highly effective against $S$. chutteri at dosages as low as $0.01 \mathrm{mg} / \ell$ (Table 8). However, temephos (Abate $\AA$ $200 \mathrm{EC}$ ) combined with $\mathrm{PBO}$ in various combinations showed no mortality (Table 8).

\section{Field trials}

Two field trials using Abate® $200 E C$ (obtained from Wefco Marketing) were conducted in the Great Fish River, on 13 December 2005, one at Coniston and one at Carlisle Bridge. These trials were undertaken

TABLE 7 Conditions of application and results of flow through gutter trials to test the toxicity of various formulations of temephos to blackfly larvae

\begin{tabular}{|c|c|c|c|c|c|c|}
\hline Trial no. & Date & $\begin{array}{l}\text { Water temp. } \\
\left({ }^{\circ} \mathrm{C}\right)\end{array}$ & $\begin{array}{l}\text { Gutter } \\
\text { channel }\end{array}$ & $\begin{array}{l}\text { Flow } \\
(\ell / s)\end{array}$ & $\begin{array}{l}\text { Dosage } \\
(\mathrm{mg} / \ell)\end{array}$ & Efficacy (\%) \\
\hline \multicolumn{7}{|c|}{ Abate ${ }^{\circledR}$ 200EC (Great Fish River) } \\
\hline $2^{*}$ & 19.07.05 & 12.5 & $\begin{array}{l}1 \\
2 \\
3 \\
4\end{array}$ & $\begin{array}{l}0.97 \\
1.23 \\
1.31 \\
1.29\end{array}$ & $\begin{array}{l}0 \\
0.010 \\
0.050 \\
0.100\end{array}$ & $\begin{array}{r}0 \\
0 \\
0 \\
50\end{array}$ \\
\hline $3^{* * *}$ & 12.12 .05 & 22.0 & $\begin{array}{l}1 \\
2 \\
3 \\
4\end{array}$ & $\begin{array}{l}0.53 \\
0.68 \\
0.81 \\
0.81\end{array}$ & $\begin{array}{l}0 \\
0.050 \\
0.100 \\
0.300\end{array}$ & $\begin{array}{r}0 \\
40 \\
77 \\
90\end{array}$ \\
\hline $4^{* * *}$ & 13.12 .05 & 25.0 & $\begin{array}{l}1 \\
2 \\
3\end{array}$ & $\begin{array}{l}- \\
1.14 \\
0.97\end{array}$ & $\begin{array}{l}0 \\
0.080 \\
0.150\end{array}$ & $\begin{array}{r}0 \\
22 \\
68\end{array}$ \\
\hline $5^{\star * *}$ & 14.12 .05 & 27.0 & $\begin{array}{l}1 \\
2 \\
3\end{array}$ & $\begin{array}{l}1.08 \\
1.11 \\
1.04 \\
\end{array}$ & $\begin{array}{l}0 \\
0.05 \\
0.50\end{array}$ & $\begin{array}{r}0 \\
65 \\
92\end{array}$ \\
\hline \multicolumn{7}{|c|}{ Abate ${ }^{\circledR}$ 200EC (Orange River) } \\
\hline $6^{* *}$ & 02.10 .06 & 20 & $\begin{array}{l}1 \\
2 \\
3 \\
4\end{array}$ & $\begin{array}{l}1.89 \\
1.74 \\
1.82 \\
1.56\end{array}$ & $\begin{array}{l}0.000 \\
0.050 \\
0.100 \\
0.500\end{array}$ & $\begin{array}{l}0 \\
0 \\
0 \\
0\end{array}$ \\
\hline $7^{* * *}$ & 03.10 .06 & 17 & $\begin{array}{l}1 \\
2 \\
3 \\
4\end{array}$ & $\begin{array}{l}1.73 \\
\text { Dry } \\
1.72 \\
1.67\end{array}$ & $\begin{array}{l}0.050 \\
0 \\
0.100 \\
0.500\end{array}$ & $\begin{array}{l}0 \\
- \\
0 \\
0\end{array}$ \\
\hline $8^{* *}$ & 03.10 .06 & 18 & $\begin{array}{l}1 \\
2 \\
3 \\
4\end{array}$ & $\begin{array}{l}1.67 \\
1.78 \\
\text { Dry } \\
1.71\end{array}$ & $\begin{array}{l}1.000 \\
5.000 \\
0 \\
12.000\end{array}$ & $\begin{array}{l}0 \\
0 \\
0 \\
0\end{array}$ \\
\hline $9^{* * *}$ & 04.10 .06 & 19 & $\begin{array}{l}1 \\
2 \\
3 \\
4\end{array}$ & $\begin{array}{l}1.68 \\
1.85 \\
1.85 \\
1.91\end{array}$ & $\begin{array}{c}5.000 \\
10.00 \\
20.00 \\
30.00\end{array}$ & $\begin{array}{l}0 \\
0 \\
0 \\
0\end{array}$ \\
\hline
\end{tabular}

* Old product supplied by SACyanamid

** New product supplied by BASF

*** New product supplied by Wefco Marketing 
to confirm the results of the gutter trials, that temephos is effective in the Great Fish River. Larval numbers prior to application were assessed at 0.2 , $0.5,1.0$ and $4 \mathrm{~km}$ downstream of Carlisle Bridge, and 5.5, 6.8 and $10.8 \mathrm{~km}$ downstream of Coniston. Larval numbers were consistently high at all sites (rating between 9 and 10). Water temperature at the time of application was moderate $\left(20^{\circ} \mathrm{C}\right)$, and the water was turbid (Secchi depth $7 \mathrm{~cm}$ ). The flow at the Pigott's Bridge gauge was estimated at $5.2 \mathrm{~m}^{3} / \mathrm{s}$, whereas the flow at Carlisle Bridge was assessed at $4.5 \mathrm{~m}^{3} / \mathrm{s}$. Larvicide was applied at a concentration of $0.1 \mathrm{ppm}$ at Coniston and $0.05 \mathrm{ppm}$ at Carlisle Bridge. Larval counts conducted the following day indicated highly successful control at both concentrations. The $0.05 \mathrm{ppm}$ application from Carlisle Bridge achieved $97 \%$ blackfly mortality at $4 \mathrm{~km}$ downstream. The $0.1 \mathrm{ppm}$ application achieved $99 \%$ mortality at Cranford, $10.8 \mathrm{~km}$ downstream of the point of application, and larval counts at the farm Mowbray, $17.7 \mathrm{~km}$ downstream, indicated mortality of $45 \%$. The results of these trials confirmed that the Abate ${ }^{\circledR}$ 200EC formulation was highly effective against blackflies in the Great Fish River.
The next step was to conduct a similar test in the Orange River. A field trial using Abate $\AA^{2} 200 E C$ was conducted in the Orange River at the top end of Kanoneiland on 4 October 2006. Flows in the two channels on either side of Kanoneiland were estimated at 62 and $26 \mathrm{~m}^{3} / \mathrm{s}$ for the right and left channels, respectively. Larval numbers prior to application were very high (rating of 10). Two formulations of Abate ${ }^{\circledR}$ 200EC were applied by boat, both at $0.1 \mathrm{ppm}$. The left channel received $8 \ell$ of Abate $\AA$ 200EC, obtained from Wefco Marketing, and the right channel received $18.5 \ell$ of Abate $\AA 200 E C$ from BASF. Larval counts conducted the following day at the road bridge, $7 \mathrm{~km}$ downstream of the point of application, showed no indication of mortality. The results of these trials confirmed that larval resistance to temephos has developed in the Orange River.

\section{Powdered and granular B.t.i.}

Preliminary results from the orbital shaking table indicated that the powdered formulation of B.t.i. $(500: 500)$ is toxic to $S$. chutteri, but results were in-

TABLE 8 Conditions of application and results of flow through gutter trials to test the toxicity of Piperonyl Butoxide combined with temephos (Abate® 200EC)

\begin{tabular}{|c|c|c|c|c|c|c|}
\hline Trial no. & Date & $\begin{array}{l}\text { Water temp. } \\
\left({ }^{\circ} \mathrm{C}\right)\end{array}$ & $\begin{array}{l}\text { Gutter } \\
\text { channel }\end{array}$ & $\begin{array}{l}\text { Flow } \\
(\ell / s)\end{array}$ & $\begin{array}{l}\text { Dosage } \\
(\mathrm{mg} / \mathrm{l})\end{array}$ & $\begin{array}{l}\text { Efficacy } \\
(\%)\end{array}$ \\
\hline \multicolumn{7}{|c|}{ PBO only (Great Fish River) } \\
\hline 1 & 09.06 .05 & 10.0 & $\begin{array}{l}1 \\
2 \\
3 \\
4\end{array}$ & $\begin{array}{l}1.83 \\
1.72 \\
1.52 \\
1.72\end{array}$ & $\begin{array}{l}0 \\
0.01 \\
0.05 \\
0.10\end{array}$ & $\begin{array}{l}0 \\
82 \\
97 \\
99\end{array}$ \\
\hline \multicolumn{7}{|c|}{ PBO plus temephos (Great Fish River) } \\
\hline & 20.07 .05 & 13.2 & $\begin{array}{l}1 \\
2 \\
3 \\
4\end{array}$ & $\begin{array}{l}1.60 \\
1.61 \\
1.34 \\
1.66\end{array}$ & $\begin{array}{l}0 \\
0.01 \mathrm{ppm} \text { (80\% temephos; } 20 \% \text { PBO) } \\
0.05 \mathrm{ppm}(80 \% \text { temephos; } 20 \% \text { PBO) } \\
0.1 \mathrm{ppm}(80 \% \text { temephos; } 20 \% \text { PBO) }\end{array}$ & $\begin{array}{l}0 \\
0 \\
0 \\
0\end{array}$ \\
\hline \multicolumn{7}{|c|}{ PBO plus temephos (Orange River) } \\
\hline 1 & 15.08 .05 & 14.6 & $\begin{array}{l}1 \\
2 \\
3 \\
4\end{array}$ & $\begin{array}{l}1.84 \\
1.76 \\
1.91 \\
2.08\end{array}$ & $\begin{array}{l}100 \% \text { PBO (0.5 ppm PBO only) } \\
80 \% \text { PBO; } 20 \% \text { temephos }(0.5 \text { ppm) } \\
20 \% \text { PBO; } 80 \% \text { temephos }(0.5 \text { ppm }) \\
0 \% \text { PBO (0.5 ppm temephos only) }\end{array}$ & $\begin{array}{l}0 \\
0 \\
2 \\
5\end{array}$ \\
\hline 2 & 15.08 .05 & 14.6 & $\begin{array}{l}1 \\
2 \\
3 \\
4\end{array}$ & $\begin{array}{l}1.84 \\
1.75 \\
1.91 \\
2.08\end{array}$ & $\begin{array}{l}100 \% \text { PBO (0.1 ppm PBO only) } \\
80 \% \text { PBO; } 20 \% \text { temephos }(0.1 \mathrm{ppm}) \\
20 \% \text { PBO; } 80 \% \text { temephos }(0.1 \mathrm{ppm}) \\
0 \% \text { PBO (0.1 ppm temephos only) }\end{array}$ & $\begin{array}{l}0 \\
0 \\
0 \\
0\end{array}$ \\
\hline $2^{*}$ & 04.10 .06 & 18.0 & $\begin{array}{l}1 \\
2 \\
3 \\
4\end{array}$ & $\begin{array}{l}1.68 \\
1.85 \\
1.85 \\
1.91\end{array}$ & $\begin{array}{l}10 \% \text { PBO (0.019 PBO + } 0.2 \text { temephos) } \\
20 \% \text { PBO (0.038 PBO + } 0.2 \text { temephos) } \\
50 \% \text { PBO (0.095 PBO + } 0.2 \text { temephos) } \\
50 \% \text { PBO (0.095 PBO only) }\end{array}$ & $\begin{array}{l}0 \\
0 \\
0 \\
0\end{array}$ \\
\hline
\end{tabular}

* PBO was applied first and temephos was applied $2 \mathrm{~h}$ later 
conclusive. A mortality of $98 \%$ was obtained for larvae exposed for $1 \mathrm{~h}$ at a dosage of $2 \mathrm{mg} / \ell$, compared to $78 \%$ mortality at half the dosage (Table 9 ). However, it took a long time to record the results and by the time the control group was counted, $3 \mathrm{~h}$ had passed and mortality was $86 \%$. Clearly, the closedsystem shaking table is unsuitable for trials exceeding $1 \mathrm{~h}$ in duration.

\section{Gutter trials}

Gutter trials conducted at Pigott's Bridge, Great Fish River, indicated that the powdered formulation of B.t.i. $(500: 250)$ is ineffective against $S$. chutteri, even at dosages of $19.38 \mathrm{mg} / \mathrm{l}$ (Table 10). A possible source of error was that walking past the gutters sometimes cast a shadow on the gutters and this would temporarily stop larvae from feeding. If this occurred during larvicide application, mortality would be reduced. However, this did not occur and larvae were feeding during the time of application, so the poor results could not have been caused by a lack of larvicide ingestion. Flow volumes in the gutter trials ranged between 0.75 and $0.91 \mathrm{l} / \mathrm{s}$ and this created average current speeds of between 0.5 and $0.8 \mathrm{~m} / \mathrm{s}$, which is within the flow preference for $S$. chutteri.
The poor results are therefore considered to be unrelated to inadequate experimental design, and were probably caused by inadequate toxicity. The formation of sticky lumps which remained behind in the syringe, could partly explain the poor results at lower concentrations, but this formulation problem is unlikely to have affected the results at higher concentrations. Gutter trials conducted at Upington on the Orange River using granular B.t.i. also showed that this formulation was ineffective against $S$. chutteri (Table 10).

\section{River trials}

A field trial conducted in Belmont Valley, Grahamstown, on 4 June 2005 indicated that the powdered formulation of B.t.i. (500:250) is ineffective against $S$. nigritarse at a dosage of $4.57 \mathrm{mg} / \ell$ (water temperature $11.5^{\circ} \mathrm{C}$; flow $62 \mathrm{l} / \mathrm{s} ; 170 \mathrm{~g}$ applied; and $0 \%$ mortality). Higher dosages were not undertaken because such concentrations would be impractical for aerial application, even if the product is applied as a dry powder. A possible reason for the poor efficacy was that the active ingredient could have settled in the sticky mass at the base of the sprayer. However, it is unlikely that all active ingredient remained in the sprayer.

TABLE 9 Conditions of application and results of orbital shaking table to test the toxicity of Bacillus thuringiensis var. israelensis (500:500) to blackfly larvae at Upington

\begin{tabular}{|c|c|c|c|c|c|c|}
\hline Date & $\begin{array}{l}\text { Water temp. } \\
\left({ }^{\circ} \mathrm{C}\right)\end{array}$ & Container no. & $\begin{array}{l}\text { Dosage } \\
(\mathrm{mg} / \mathrm{\ell})\end{array}$ & No. dead & No. alive & $\%$ dead \\
\hline 07.09 .04 & Not recorded & $\begin{array}{r}1 \\
2 \\
3 \\
4 \\
5 \\
6 \\
7 \\
8 \\
9 \\
10 \\
11 \\
12 \\
13 \\
14 \\
15 \\
16 \\
17 \\
18 \\
19 \\
20 \\
21 \\
22 \\
23 \\
24\end{array}$ & $\begin{array}{l}0^{*} \\
0.000000 \\
0.000001 \\
0.000002 \\
0.000004 \\
0.000008 \\
0.000015 \\
0.000031 \\
0.000061 \\
0.000122 \\
0.000244 \\
0.000488 \\
0.000977 \\
0.001953 \\
0.003906 \\
0.007813 \\
0.015625 \\
0.031250 \\
0.062500 \\
0.125000 \\
0.250000 \\
0.500000 \\
1.000000 \\
2.000000\end{array}$ & $\begin{array}{r}38 \\
26 \\
23 \\
14 \\
30 \\
23 \\
28 \\
29 \\
8 \\
24 \\
15 \\
21 \\
12 \\
30 \\
23 \\
18 \\
47 \\
34 \\
39 \\
30 \\
48 \\
26 \\
41 \\
56\end{array}$ & $\begin{array}{r}6 \\
10 \\
5 \\
8 \\
12 \\
15 \\
14 \\
10 \\
40 \\
4 \\
22 \\
37 \\
13 \\
36 \\
34 \\
26 \\
29 \\
26 \\
31 \\
11 \\
11 \\
4 \\
11 \\
1\end{array}$ & $\begin{array}{l}86 \\
72 \\
82 \\
64 \\
72 \\
61 \\
67 \\
74 \\
17 \\
86 \\
40 \\
36 \\
48 \\
45 \\
40 \\
41 \\
62 \\
57 \\
56 \\
73 \\
81 \\
87 \\
78 \\
98\end{array}$ \\
\hline
\end{tabular}

* Control 
TABLE 10 Conditions of application and results of flow through gutter trials to test the toxicity of various dry formulations of Bacillus thuringiensis var. israelensis to blackfly larvae

\begin{tabular}{|c|c|c|c|c|c|c|}
\hline Trial no. & Date & $\begin{array}{l}\text { Water temp. } \\
\left({ }^{\circ} \mathrm{C}\right)\end{array}$ & $\begin{array}{l}\text { Gutter } \\
\text { channel }\end{array}$ & $\begin{array}{l}\text { Flow } \\
(\ell / s)\end{array}$ & $\begin{array}{l}\text { Dosage } \\
\text { (mg/e) }\end{array}$ & Efficacy (\%) \\
\hline \multicolumn{7}{|c|}{ Standard powder formulation (500:250) (Great Fish River) } \\
\hline & 03.06 .05 & 11.5 & $\begin{array}{l}1 \\
2 \\
3 \\
4\end{array}$ & $\begin{array}{l}0.88 \\
0.86 \\
0.75 \\
0.83\end{array}$ & $\begin{array}{l}0^{*} \\
0.9 \\
2.2 \\
6.0\end{array}$ & $\begin{array}{l}0 \\
0 \\
0 \\
0\end{array}$ \\
\hline \multicolumn{7}{|c|}{ Double strength powder formulation (500:500) (Great Fish River) } \\
\hline & 04.06 .05 & 11.2 & $\begin{array}{l}1 \\
2 \\
3 \\
4\end{array}$ & $\begin{array}{l}0.85 \\
0.91 \\
0.82 \\
0.86\end{array}$ & $\begin{array}{l}0^{*} \\
3.7 \\
8.1 \\
19.4\end{array}$ & $\begin{array}{l}0 \\
0 \\
0 \\
0\end{array}$ \\
\hline & 04.06 .05 & 11.2 & $\begin{array}{l}1 \\
2 \\
3\end{array}$ & & & \\
\hline \multicolumn{7}{|c|}{ Granular formulation (Orange River) } \\
\hline & 03.10 .06 & 18 & $\begin{array}{l}1 \\
2 \\
3 \\
4\end{array}$ & $\begin{array}{l}1.62 \\
1.79 \\
1.79 \\
1.85\end{array}$ & $\begin{array}{l}0.5 \\
0.9 \\
1.9 \\
9.0\end{array}$ & $\begin{array}{l}0 \\
0 \\
0 \\
0\end{array}$ \\
\hline
\end{tabular}

* Control

\section{DISCUSSION}

\section{Permethrin}

The results of this study indicate that the permethrin formulation RD95B is highly effective against blackflies at a concentration of $0.043 \mathrm{mg} / \ell$, and was by far the most promising larvicide tested. However, the chemical has two problems, namely potential for resistance and impacts on the environment.

Resistance to permethrin has been reported for a wide variety of insects and cross-resistance to a range of synthetic pyrethroids has been reported (Cox 1998). The use of permethrin, or any additional replacement larvicide for temephos, in the Orange River Blackfly Control Programme would have to be used within a careful management framework to avoid resistance developing again.

Permethrin decomposes rapidly in water and, while it is known to be highly toxic to aquatic organisms, including fish, it is relatively safe to people. MuirheadThomson (1977) noted that permethrin was 40 times more toxic than Abate ${ }^{\circledR}$, but raised concerns on its effects on non-target organisms. Wide spectrum larvicides may result in the undesirable eradication of most aquatic invertebrates and a change in ecosys- tem equilibrium and functioning. Kreutzweiser \& Kingsbury (1987) noted that river systems took 1-18 months to recover from applications of permethrin.

Impacts on non-target organisms may often be detected through increases in the density of drifting invertebrates. Kreutzweiser \& Kingsbury (1987) reported a major increase in downstream drift of nontarget organisms following an application of permethrin in forest streams in Canada. Such impacts would be exacerbated through further exposure to aquatic invertebrates as they drift downstream with the "slug" of larvicide (Muirhead-Thomson 1977). While synthetic pyrethroids have been shown to have moderate acute toxicity to birds $\left(\mathrm{LD}_{50}=1000\right.$ $\mathrm{mg} / \mathrm{kg}$ ) (SPIOP 1986), the US Environmental Protection Agency has classified permethrin as a carcinogen, since it causes cancerous tumours in lung and liver tissue of mice (Cox 1998). Permethrin has been widely reported as being highly toxic to aquatic invertebrates (Mueller-Beilschmidt 1990; Cox 1998), with an $L_{50}$ of less than 1.0 ppb, which is similar to that used for pest blackfly control (Smith \& Stratton 1986). The aquatic invertebrate groups most sensitive to permethrin are mayfly, damselflies and zooplankton (Anderson 1982; Smith \& Stratton 1986; SPIOP 1986). Such impacts could potentially 
have a significant indirect effect on fish, through diminished food supplies (SPIOP 1986).

Permethrin is highly toxic to fish (Cox 1998), particularly at lower water temperatures, and to smaller fish (Hill 1985), since fish lack the enzymes to break permethrin down (Haya 1989). The $\mathrm{LC}_{50}$ values of many fish species tested is less than $1.0 \mathrm{ppm}$ (World Health Organization 1990), the same concentration recommended for pest blackfly control. Permethrin shows intermediate toxicity to fish within the spectrum of pyrethroid toxicities, although it is also noted that pyrethroids in general are highly toxic to fish, with about $40 \%$ of $\mathrm{LC}_{50}$ values for fish being less than $1 \mathrm{ppb}$ (Smith \& Stratton 1986).

Differences in mortalities between gutter trials and river trials at the same concentrations recorded in this study may be attributed to differences in exposure time and/or interactions between permethrin and suspended organic matter. Muirhead-Thomson (1987) reported that pyrethroids were more toxic to fish in the laboratory than in natural water because they adhere to suspended organic matter in the water and sediment.

\section{Temephos}

Formulations of temephos (Abate $\AA 200 E C$ ) were highly effective against blackfly in the Great Fish River, but the same products were ineffective in the Orange River. The results indicate clearly that larval resistance to temephos has developed in the Orange River, but the mechanisms of resistance were not investigated in this study.

Temephos has a number of chemical bonds that are available for metabolic attack by oxidases or esterases. Laboratory studies in West Africa have shown that resistance to temephos among the $S$. damnosum complex is associated mainly with detoxication by esterases, but oxidase enzyme systems are also involved in some members of the complex (Kurtak 1990). Cross-resistance tests showed no cross-resistance to carbamate insecticides with these mechanisms, but negative correlations with most pyrethroids (Kurtak 1990).

The feasibility of "reversing" the resistance through the use of piperonyl butoxide was investigated. The results showed that piperonyl butoxide on its own is highly toxic to blackfly larvae. This contradicts the generally held view that piperonyl butoxide is nontoxic on its own. Various combinations of piperonyl butoxide and temephos showed no enhanced toxicity as predicted.

\section{B.t.i. formulations}

The physical properties of the standard dry powder concentrated formulation of B.t.i. (500:250) were unsuitable for blackfly control, firstly because of poor vertical dispersion and rapid settling in water. The implication of this is that downstream carry is likely to be limited. Secondly, the product forms sticky lumps when mixed with water and this is likely to cause clogging problems with application equipment, should the product be applied as a wet formulation. A possible solution to this problem would be to apply the product as a dry powder, but this is likely to restrict applications to periods when wind is not blowing. The slow-release granular formulation, by contrast, showed excellent dispersal properties.

A more serious problem was that gutter and field trials found that all formulations tested were ineffective against blackflies. This was unlikely to have been due to low water temperatures, since water temperatures always exceeded the $10^{\circ} \mathrm{C}$ temperature threshold of efficacy found by De Moor \& Car (1986). Concentrations of B.t.i. applied in these trials were also within the range used by Parkes \& Kalff (2004), who applied B.t.i. to larval simuliids in rivers in southern Quebec at concentrations of $1 \mathrm{~g} / \mathrm{l} / \mathrm{s}$ and achieved in excess of $80 \%$ mortality. Similarly, De Moor \& Car (1986) achieved equivalent mortalities in S. chutteri in the Orange River, at concentrations of $1.6 \mathrm{ppm}$ per $10 \mathrm{~min}$.

\section{CONCLUSIONS}

Various potential larvicides for use during high flow conditions were investigated in laboratory, gutter and river trials, but none was found to be suitable. This study therefore failed to identify or register a suitable larvicide for use during high flow conditions. Permethrin was highly effective against blackfly larvae, but was rejected because of its detrimental impacts on non-target fauna. Various formulations of locally produced dry B.t.i. were tested, but these were ineffective against blackflies.

Trials with $20 \%$ EC formulations of temephos in the Great Fish River found that the product is effective, but gutter and river trials in the Orange River showed no efficacy, even at dosages that were 300 times the recommended dose. The results confirmed that larval resistance to temephos has developed in the Orange River.

The feasibility of "reversing" the resistance to temephos through the use of piperonyl butoxide was in- 
vestigated. Various combinations of piperonyl butoxide and temephos were tested, but none showed enhanced toxicity, as predicted. The results showed that piperonyl butoxide alone is highly toxic to blackfly larvae and non-target organisms, and is therefore not recommended for use in blackfly control.

The natural recovery from resistance will depend on the rate at which the population mixes with non-resistant populations. The middle and lower Orange River is geographically isolated, therefore the resistant population of blackflies is likely to remain so for some time. How long reversal to resistance will take, is unknown, but findings elsewhere have shown that the development of resistance is much more rapid than its reversal.

The risks of larval resistance to temephos were well known when the programme started in 1991, and nothing was done to monitor resistance or test the development of resistance when it was first suspected in 2000. This underscores the need for radical improvements in the management of the control programme.

Resistance to B.t. toxins has for many years been considered remote because of the complexity of the toxin, containing multiple toxins with multiple target sites (McGaughey \& Whalon 1992; McGaughey 1994). However, resistance to B.t.i. has been documented in the laboratory for at least eight species of pest, and the diamond backed moth (Plutella xylostella) has developed widespread resistance in the field (Tabashnik 1994). Possible physiological mechanisms of resistance include changes in the gut $\mathrm{pH}$ or enzymes that would deactivate the toxic protein (McGaughey \& Whalon 1992). In some moths, resistance is due to changes in the binding sites in the insect mid gut (McGaughey \& Whalon 1992; Tabashnik 1994). Although resistance to B.t.i. has not been reported for blackflies (Kurtak et al. 1989), there is a need to remain vigilant and to implement an operational strategy that minimizes the risk of resistance developing.

\section{ACKNOWLEDGEMENTS}

We thank the Water Research Commission, AgriNoord Kaap, the Orange River Producers Alliance and Plant Health Products for financial support. The WRC Steering Committee, and in particular Steve Mitchell (Water Research Commission) and Dirk Steenkamp (national Department of Agriculture), are thanked for their input comments over the course of this research. Nkosinathi Mtwa and Vivian
McPherson are thanked for field assistance. Keith Craig (Kwandwe Private Game Reserve, Eastern Cape Province) and Mike Palmer (Strowan Farm, Grahamstown) are thanked for facilitation in the Great Fish River trials. Two anonymous reviewers are thanked for their comments and suggestions.

\section{REFERENCES}

ANDERSON, R.L. 1982. Toxicity of fenvalerate and permethrin to several nontarget aquatic invertebrates. Environmental Entomology, 11:1251-1257.

COX, C. 1998. Insecticide factsheet: Permethrin. Journal of Pesticide Reform, 18:14-20.

DE MOOR, F.C. \& CAR, M. 1986. A field evaluation of Bacillus thuringiensis var. israelensis as a biological control agent for Simulium chutteri (Diptera: Nematocera) in the middle Orange River. Onderstepoort Journal of Veterinary Research, 53:4350 .

GORDON, N.D., MCMAHON, T.A. \& FINLAYSON, B.L. 1992. Stream hydrology: An introduction for ecologists., Chichester, England: John Wiley \& Sons.

HAYA, K. 1989. Toxicity of pyrethroid insecticides to fish. Environmental Toxicology and Chemistry, 8:331-391.

HILL, I.R. 1985. Effects on non-target organisms in terrestrial and aquatic environments, in The pyrethroid insecticides, edited by J.P. Leahey. London, UK: Taylor \& Francis.

HOWELL, C.J. \& HOLMES, G.W. 1969. The control of Simuliidae in the Vaalharts irrigation complex. Journal of the South African Veterinary Medical Association, 40:59-67.

JONES, D.G. 1998. Piperonyl butoxide: The insecticide synergist. San Diego, California: Academic Press.

KREUTZWEISER, D.P. \& CAPPEL, S.S. 1992. A simple streamside test system for determining acute lethal and behavioural effects of pesticides on aquatic insects. Environmental Toxicology and Chemistry, 11:993-999.

KURTAK, D.C., BACK, C., CHALIFOUR, A., DOANNIO, J., DOSSOU-YOVO, J., DUVAL, J., GUILLET, P., MEYER, R., OCRAN, M.R. \& WAHLE, B. 1989. Impact of B.t.i. on black fly control in the Onchocerciasis Program Control in West Africa. Israel Journal of Entomology, 23:21-38.

KURTAK, D.C. 1990. Maintenance of effective control of Simulium damnosum in the face of insecticide resistance. Acta Leiden, 59:95-112.

LÉVÊQUE, C., HOUGARD, J.M., RESH, V., STATZNER, B. \& YAMÉOGO, L. 2003. Freshwater ecology and biodiversity in the tropics: what did we learn from 30 years of Onchocerciasis control and the associated biomonitoring of West African rivers? Hydrobiologia, 50:23-49.

MCGAUGHEY, W.H. 1994. Problems of insect resistance to Bacillus thuringiensis. Agriculture, Ecosystems and Environment, 49:95-102.

MCGAUGHEY, W.H. \& WHALON, M.E. 1992. Managing insect resistance to Bacillus thuringiensis toxins. Science, 258: 1451-1455.

MUELLER-BEILSCHMIDT, D. 1990. Toxicology and environmental fate of synthetic pyrethroids. Journal of Pesticide Reform, 10:32-37.

MUIRHEAD-THOMSON, R.C. 1977. Comparative tolerance levels of black fly (Simulium) larvae to permethrin (NRDC 143) and temephos. Mosquito News, 37:76; 172-179. 
MUIRHEAD-THOMSON, R.C. 1987. Pesticide impact on stream fauna with special reference to macroinvertebrates. Cambridge, UK: University Press.

MYBURGH, E. 1999. The control of blackflies in South Africa. Internal report prepared for the National Department of Agriculture, Directorate of Agricultural Resource Conservation, by the Onderstepoort Veterinary Institute for the contract year 1998/1999.

MYBURGH, E. \& NEVILL, E.M. 2003. Review of blackfly (Diptera: Simuliidae) control in South Africa. Onderstepoort Journal of Veterinary Research, 70:307-317.

OCRAN, M.H. 1989. Larvicide screening methodology for classifical chemical compunds in the Onchocerciasis Control Programme (OCP). World Health Organization. WHO/VBC/89. 969.

PALMER, R.W. 1994. A rapid method of estimating abundance of immature blackflies (Diptera: Simuliidae). Onderstepoort Journal of Veterinary Research, 61:117-126.

PALMER, R.W. 1997. Principles of integrated control of blackflies (Diptera: Simuliidae) in South Africa. Pretoria: Water Research Commission (WRC Report No. 650/1/97).

PARKES, A.H. \& KALFF, J. 2004. Feeding by black fly (Diptera: Simuliidae) larvae causes downstream losses in phytoplank- ton, but not bacteria. Journal of the North American Benthological Society, 23:780-792.

SIBLEY, P.K. \& KAUSHIK, N.K. 1991. Toxicity of microencapsulated permethrin to selected non-target aquatic invertebrates. Archives of Environmental Contamination and Toxicology, 20:168-176.

SMITH, T.M. \& STRATTON, G.W. 1986. Effects of synthetic pyrethroid insecticides on nontarget organisms. Residue Reviews, 97:93-120.

SPIOP 1986 [Subcommittee on Pesticides \& Industrial Organic Pesticides, Associate Committee on Scientific Criteria for Environmental Quality, National Research Council of Canada]. Pyrethroids: Their effect on aquatic and terrestrial ecosystems. NRCC No. 24376. Ottawa, Canada: Environmental Secretariat, National Research Council of Canada.

TABASHNIK, B.E. 1994. Evolution of resistance to Bacillus thuringiensis. Annual Review of Entomology, 39:47-79.

WHO 1988. The WHO recommended classification of pesticides by hazard and guidelines to classification. Geneva: World Health Organization.

WHO 1990. Environmental health criteria. Vol. 94, Permethrin. Geneva: World Health Organization. 